Trans Tasman Surveyor, Vol. 1, No. 1, 29-38, 1995

\title{
Implications of Incorporating Customary Land Tenure Data into a Land Information System
}

\author{
by \\ Mele E. T. Rakai \\ Fiji Land Information System Support Centre \\ Department of Lands and Surveys \\ Box 2222, Govt Buildings, Suva, FIJI. \\ and \\ Ian P.Williamson \\ Professor of Surveying and Land Information \\ Department of Geomatics \\ The University of Melbourne, \\ Parkville, Victoria, AUSTRALIA 3052
}

\section{Abstract}

Land Information Systems (LIS) have been primarily developed to serve the needs of countries that use a 'western' style land market where individual land rights are the norm. However many countries that have a large proportion of lands held under customary land tenures where communally held land rights are common, are also wishing to establish LIS. For these countries LIS is a tool to facilitate the management and administration of their land resources, preserve their customs and traditions and promote the development of a market economy. In order to be effective, the LIS introduced into these countries will need to incorporate customary land tenure data. This paper considers the implications of incorporating such customary land tenure data into a LIS.

Firstly the attributes of western land tenures that are currently used in Land Information Systems are reviewed; then drawing examples from Fiji, the paper examines some of the attributes of customary tenure that could be entered into a LIS. This is followed by a discussion of some of the major issues associated with including customary tenure data in a LIS.

\section{Introduction}

Land Information Systems (LIS) have developed in the 'western' world, primarily in response to the need to improve efficiency, to reduce reliance on an expensive labour force, and to capitalise on the advances being achieved in computer and communications technology.

In addition, western countries have usually developed land registration systems that record individual property rights and other details of individual land parcels with the primary purpose of supporting a free land market economy based on an efficient system of buying, selling, leasing and mortgaging land. Historically LIS were aimed primarily at improving the efficiency of countries having similar dynamic property markets. This inevitably meant that the LIS would be based on western concepts of land tenure with a focus on individual rights, including the perception of land as a commodity and as an agent for economic growth.

However de Soto (1993) has pointed out that as many as two thirds of the countries of the world are still 
classified as developing countries. The majority of these countries operate customary land tenure systems that do not perceive land as a commodity that can be bartered and exchanged for personal economic gain. Given that these countries will almost inevitably introduce some form of land information systems into their jurisdictions, some effort must now be spent on examining the appropriateness of LIS for such countries. Unless this is done, the LIS may not be applicable for countries that encompass lands held under customary land tenure, but more importantly it may have some negative impact on traditional social structures.

This paper examines some of the issues that a developing country with a large proportion of customary land tenures may face when attempting to implement a LIS. It first reviews the attributes of western land tenures that are currently used in Land Information Systems to provide a better understanding of the concept of a "western" LIS. Using Fiji as a case study it then examines some of the attributes of customary tenure that may need to be entered into a LIS, and discusses some of the major issues associated with incorporating customary tenure data into a LIS.

\section{Definitions}

Land Information Systems need not be computerised; however the advent of computerisation has meant that most LIS are being computerised in order to capitalise on the advantages of using computers - such as easier data storage, more efficient data retrieval and dissemination.

A computerised LIS is defined in this paper as being:

"A system for managing land related information that uses modern technology to create and maintain an up to date land related data base and to disseminate resulting land information, and is ultimately controlled by the surrounding organisational, institutional and social framework."

In the context of this paper, LIS are typically major management oriented administrative systems on a regional, state or national basis that support government or semi-government activities such as land registration, land taxation, land administration, planning, land subdivision, local government administration and the management of utilities and services.

Land tenure is an important factor in the management, administration and use of the land resources of any country and as a result is a key issue in the creation of a LIS. Land tenure describes the terms and conditions under which land is held, and the rights, responsibilities and restrictions that are attached to the user of the land. It is concerned for example, with the way in which land is valued, used and regulated; the way in which it is spatially divided among groups and individuals; and the way in which the benefits from the land are distributed within society.

Land tenure arises in a number of ways as described by Falloux (1989):

- by tradition (customary "law");

- by an Act or Code passed by the Legislature;

- by individual contract, formal or informal, regarding the use of land; and

- informally, through individuals occupying (usually public) land and establishing some degree of tenure over the land through a particular land use.

More specifically customary land tenure arises as a result of the accepted practices and traditions of a traditional society in obtaining, using, distributing and disseminating its land. It is defined in the context of this paper as "the rules accepted by a group of the ways in which land is held, used, transferred and transmitted" (Noronha and Lethem, 1983). The rules may have the "force of law", that is they can be enforced by the courts of a country despite the fact that they may be unwritten and not incorporated or documented in a statute. 
A successful LIS requires an information system that is able to store and provide all information relevant to the nature, extent and possession of land rights. The widespread practice in 'western' countries, of registering all documents and dealings that affect the ownership of land has facilitated this task.

The standard western LIS has adopted the parcel of land as the basic organisational unit for referencing land tenure data and information. This basic organisational unit, the land parcel, has the function of linking all disparate data sets with each other. The attributes used in the 'western' LIS can be classified according to two types -- spatial attributes and textual or non-spatial attributes.

The spatial attributes of a land parcel determine the following :

- location (state/province, district, block, absolute coordinates)

- bounds (adjoining parcels and features such as roads)

- size (area)

- shape (lengths of sides, angles, azimuths or bearings, relative coordinates)

These attributes can be collected directly by conventional field surveys or remotely by means of aerial photography, or through some combination of these methods.

Textual or non-spatial attributes of the land parcel determine the following:

- the nature of the land tenure rights - rights, restraints, responsibilities pertaining to that right

- the identification of those who hold them - names, addresses

The textual attributes, which generally require some form of adjudication or legal investigation, include :

- the length of time the use of the right may continue;

- the right of inheritance;

- what rent is due, and when;

- the right to sell the land;

- the right to mortgage the land;

- the right to lease the land;

- the nature and limits of land use;

- the rights of reversion; and

- residence and improvement requirements.

The following is a list of typical tenure information that may be found in a 'western' land tenure based LIS:

- Ownership: name, postal address, street address

- Occupier: name, postal address, street address

- Full Private Rights: title reference, dealings, transfer documents

- Parcel Boundaries and Location:

- Legal description (PID) eg Plan \& Lot No.

- Cadastral boundary data, Map Reference

- Private Restrictions: Mortgage, Covenants, Caveats

- Public Restrictions: Zoning

- Limited Rights: Leases, Water

- Land Value: Assessed, Market

- Other ownership attributes: Historic descriptions

- Other Parcel attributes: land use, cultural features (buildings, roads)

\section{Attributes of customary land tenure for a LIS}


Customary land tenures can be classified according to formal and informal land tenures as is the case in Fiji.

Formal customary land tenures are those that have been regulated by Government laws and regulations and are therefore officially recognised and sanctioned. These include such features as the universal classification of Fijian land owning groups into tokatoka or mataqali; the universal sanctioning of the aristocratic rights of chiefs to a portion of the yields of the land being epitomised in their being permanently apportioned a percentage of all lease rentals.

Informal customary land tenures are those that are not officially sanctioned or recognised by the courts or Government, but are practised and accepted as an unspoken long term customary practice. These systems include such things as complying with traditional beliefs and customary taboos : eg lala - providing services to chiefs. Table 1 compares some of the attributes of customary tenures with the attributes of 'western' tenures.

As expected, most of the formal attributes of customary land tenures can and are being accommodated into the LIS. Informal attributes of customary land tenures however are yet to be systematically documented and included into an LIS. Tables 2 - 4 list some attributes of informal customary land tenures that could be incorporated into a LIS with reference to Fiji.

Table 2 describes the rights under customary land tenure and discusses the advantages and disadvantages of incorporating those rights in a LIS. Table 3 describes the types of restraints or restrictions that attach to the rights operating under customary tenure and discusses the advantages and disadvantages of including them in a LIS. Table 4 describes the responsibilities attached to the rights operating under a system of customary tenure and discusses the advantages and disadvantages of including these responsibilities in a LIS.

\begin{tabular}{|c|c|c|c|}
\hline & $\begin{array}{l}\text { Informal Customary } \\
\text { Tenures }\end{array}$ & $\begin{array}{l}\text { Formal Customary } \\
\text { Tenures }\end{array}$ & Western Tenures \\
\hline $\begin{array}{l}\text { Rights } \\
\text { Legitimised: }\end{array}$ & $\begin{array}{l}\text { - by recognition and } \\
\text { acceptance by } \\
\text { community (and } \\
\text { reinforced by } \\
\text { occupation and } \\
\text { amicable } \\
\text { relationships within } \\
\text { community) }\end{array}$ & $\begin{array}{l}\text { - statutorily by } \\
\text { legislation }\end{array}$ & $\begin{array}{l}\text { - statutorily by } \\
\text { legislation }\end{array}$ \\
\hline $\begin{array}{l}\text { Land Rights } \\
\text { Transmitted: }\end{array}$ & $\begin{array}{l}\text { - for land-owning } \\
\text { members: inheritance, } \\
\text { but qualified by } \\
\text { place of residence, } \\
\text { need, gifts, number } \\
\text { of children, etc. - } \\
\text { for immigrants: } \\
\text { transmitted in } \\
\text { response to their } \\
\text { needs, or other } \\
\text { circumstances eg. } \\
\text { gift, rewards. }\end{array}$ & $\begin{array}{l}\text { - statutorily, } \\
\text { only by } \\
\text { inheritance or } \\
\text { legally } \\
\text { documented gift } \\
\text { - by sale, for } \\
\text { registered } \\
\text { leases - all by } \\
\text { statute }\end{array}$ & $\begin{array}{l}\text { - By inheritance } \\
\text { - By sale - By } \\
\text { gift - all by } \\
\text { statute }\end{array}$ \\
\hline Land Used: & individually & individually & individually \\
\hline Land Owned: & $\begin{array}{l}\text { - by group (groups } \\
\text { varying in size and } \\
\text { type, according to } \\
\text { need and } \\
\text { circumstances, } \\
\text { therefore changeable } \\
\text { with time and } \\
\text { circumstances) }\end{array}$ & $\begin{array}{l}\text { - by group } \\
\text { (group size \& } \\
\text { type permanently } \\
\text { and legally } \\
\text { defined (eg } \\
\text { mataqali ) ) }\end{array}$ & $\begin{array}{l}\text { - by individual } \\
\text { or corporation, } \\
\text { but held } \\
\text { allodially by } \\
\text { state/crown }\end{array}$ \\
\hline $\begin{array}{l}\text { Conditions } \\
\text { for Reversion } \\
\text { of Land } \\
\text { Rights from } \\
\text { individual } \\
\text { back to Group }\end{array}$ & $\begin{array}{l}\text { - abandoned land - } \\
\text { extinction of } \\
\text { individual user } \\
\text { sub-group - } \\
\text { renouncement of } \\
\text { allegiance to group - } \\
\text { expiry of temporary } \\
\text { user rights }\end{array}$ & $\begin{array}{l}\text { - appointed term } \\
\text { eg two years of } \\
\text { absenteeism from } \\
\text { village - but } \\
\text { rarely, if ever, } \\
\text { enforced }\end{array}$ & $\begin{array}{l}\text { - not applicable, } \\
\text { since rights held } \\
\text { either in } \\
\text { perpetuity for } \\
\text { Freeholds, or for } \\
\text { term of lease for } \\
\text { Leaseholds. }\end{array}$ \\
\hline Social, & village greens - & not always & none (apart from \\
\hline
\end{tabular}




\begin{tabular}{|c|c|c|c|}
\hline $\begin{array}{l}\text { Mystical or } \\
\text { Religious } \\
\text { Sites }\end{array}$ & $\begin{array}{l}\text { sacred ancestral } \\
\text { grounds }\end{array}$ & $\begin{array}{l}\text { recognised } \\
\text { statutorily }\end{array}$ & $\begin{array}{l}\text { reserves set } \\
\text { aside for } \\
\text { cemeteries or } \\
\text { churches for } \\
\text { logistic purposes) }\end{array}$ \\
\hline $\begin{array}{l}\text { Degree Of } \\
\text { Rights Held }\end{array}$ & $\begin{array}{l}\text { - vary according to } \\
\text { political/social } \\
\text { status, - may not be } \\
\text { distinct or clear cut }\end{array}$ & $\begin{array}{l}\text { - vary according } \\
\text { to political/ } \\
\text { social status - } \\
\text { vary according } \\
\text { to size of land } \\
\text { allocation }\end{array}$ & $\begin{array}{l}\text { - equally by } \\
\text { individuals }\end{array}$ \\
\hline
\end{tabular}

\section{Table 1: Comparative Attributes Of Land Tenure Systems in Fiji}

\author{
Rights under \\ Customary \\ Tenure \\ Acquisition \\ Rights of \\ individual by \\ inheritance \\ Acquisition \\ Rights of \\ older siblings

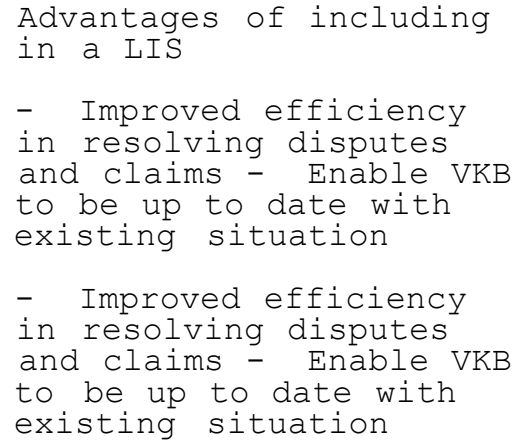

Acquisition Rights of females

Acquisition Rights of chiefs

Land use rights

Fishing Rights

Non-official Vakavanua land rights of migrant settlers
- Improved efficiency in resolving disputes and claims - Enable VKB to be up to date with existing situation

- Improved efficiency in resolving disputes and claims - capability of LIS to store historic data will facilitate verification of chiefs entitled to receive lease rentals, in cases of dispute

- Allows monitoring of land use for : * land conservation; * allocation of land rights based on land usage, when disputes occur; * compensation * monitoring of problems of access, topography, soils, etc Can evaluate value of lands and effectiveness of existing land tenure - Allows monitoring of use for: * compensation * conservation Improved efficiency in resolving disputes and claims

Monitoring of such incidents to allow assessment of reality of vakavanua arrangements
Disadvantages of including in a LIS

- Danger of flexibility of original system eventually being lost, if LIS taken as final authority. - Possible cause of dissension, particularly with loss of flexibility

- Danger of flexibility of original system eventually being lost, if LIS taken as final authority. - Potential for future conflicts and dissension, when rights of younger siblings (and their descendants) are not officially recognised

- Danger of flexibility of original system eventually being lost - Possible cause of dissension, if descendants attempt to take dominant decision making role in future village affairs - Danger of flexibility of original system eventually being

lost - Possible cause of great dissension in verifying authenticity of oral evidence relating to chiefly rights, since oral evidence can be very subjective - Possible cause of failure of LIS, if chiefs find this measure offensive - Can eventually override the existing traditional way of encouraging disputants to resolve their differences through dialogue and consideration of other's needs - thus, can hasten the slow conversion to individualism and materialism. - Can be a source of petty bickering

- If inaccurately defined

initially, potential for explosive disputes later - Difficult to get unanimous agreement

Can lead to LIS data being used as basis to formalise arrangements, using existing legislation, such as the ALTA 
Table 2 : Rights of Customary Tenure : Advantages \& Disadvantages of Including in a LIS in Fiji

\begin{tabular}{|c|c|c|}
\hline Restraints & $\begin{array}{l}\text { Advantages of including } \\
\text { in a LIS }\end{array}$ & Disadvantages of including in a LIS \\
\hline $\begin{array}{l}\text { Traditional } \\
\text { Customs - eg } \\
\text { fishing and } \\
\text { cultivation } \\
\text { restrictions } \\
\text { when chief } \\
\text { dies }\end{array}$ & $\begin{array}{l}\text { - More cultural } \\
\text { awareness, thus less } \\
\text { conflicts with land } \\
\text { developers and foreigners }\end{array}$ & $\begin{array}{l}\text { - Private, personal property } \\
\text { publicised - Misinterpreted } \\
\text { restraints - source of dissension } \\
\text { and conflicts }\end{array}$ \\
\hline $\begin{array}{l}\text { Spiritual - } \\
\text { eg access to } \\
\text { ancestral/sacr } \\
\text { ed sites } \\
\text { restricted } \\
\text { due to } \\
\text { possible } \\
\text { repercussions }\end{array}$ & $\begin{array}{l}\text { - More cultural } \\
\text { awareness, thus less } \\
\text { conflicts with land } \\
\text { developers and foreigners }\end{array}$ & $\begin{array}{l}\text { - cultural insensitivity could } \\
\text { lead to possible desecration of } \\
\text { sites, when depicted in LIS }\end{array}$ \\
\hline $\begin{array}{l}\text { Legislative } \\
\text { restraints on } \\
\text { land sales, } \\
\text { leases, etc. - } \\
\text { eg majority } \\
\text { group consent } \\
\text { required }\end{array}$ & $\begin{array}{l}\text { - Monitor frequency of } \\
\text { disallowed group } \\
\text { consents, and reasons why }\end{array}$ & $\begin{array}{l}\text { - Misinterpreted LIS information } \\
\text { on restraints can be potential } \\
\text { source of dissension and conflicts }\end{array}$ \\
\hline $\begin{array}{l}\text { Concept of } \\
\text { taking only } \\
\text { enough for } \\
\text { yourself and }\end{array}$ & $\begin{array}{l}\text { - Monitoring of land use } \\
\text { will pick out those } \\
\text { selfishly exceeding } \\
\text { their understood quota }\end{array}$ & - Technically difficult to document \\
\hline
\end{tabular}

Table 3: Restraints Of Customary Tenure : Advantages \& Disadvantages Of Including in a LIS in Fiji

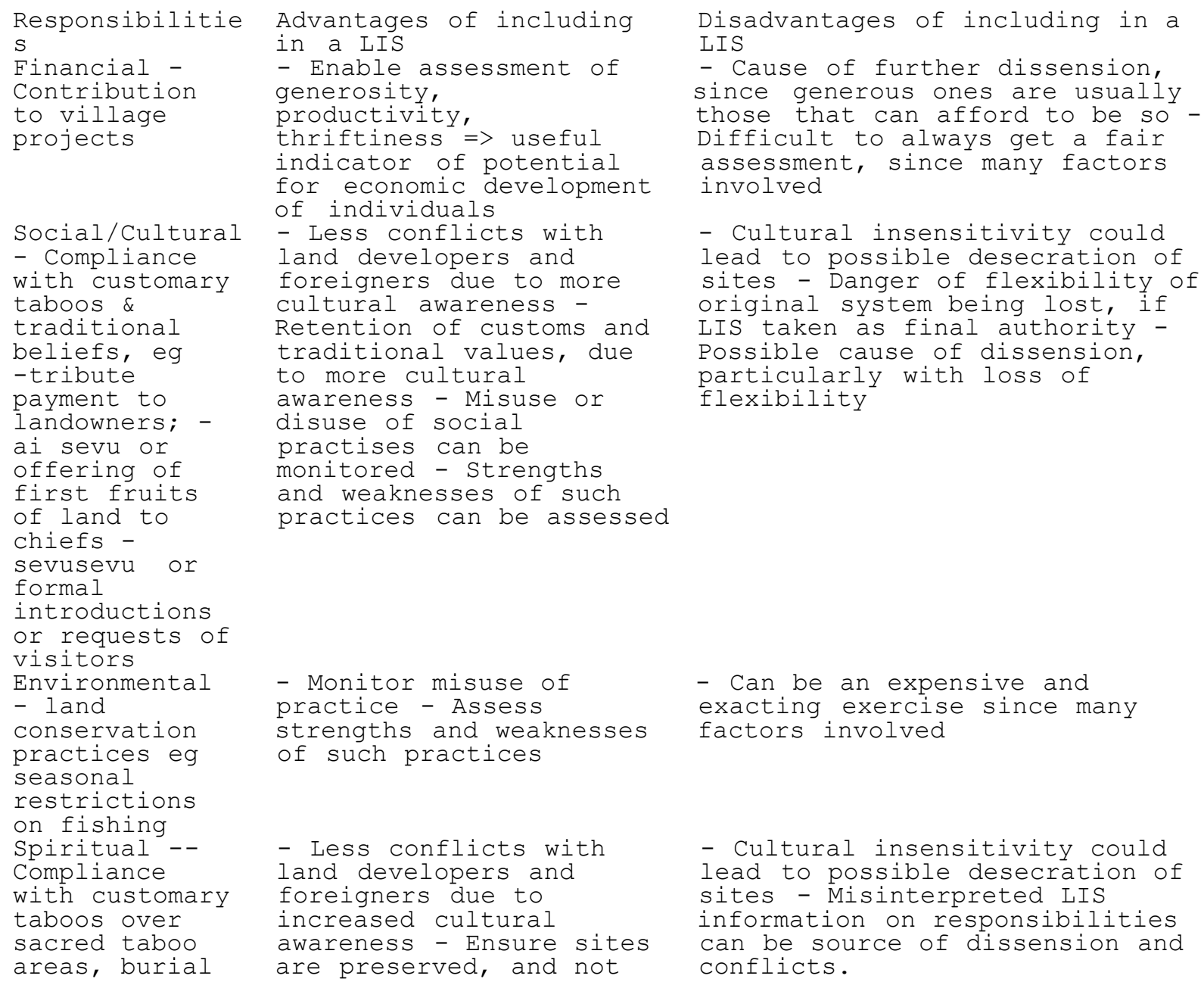




\section{Issues associated with incorporating customary tenure attributes in a LIS in Fiji}

Incorporating customary land tenure data into a LIS raises issues of economic, social, cultural, technical, institutional, legal and political significance.

\section{General Issues}

One of the significant questions about incorporating customary land tenure data into a LIS is who is going to fund the exacting task that it would entail. Incorporating customary land tenure data would entail among others: documenting attributes peculiar to every region; resurveying areas that have been the subject of intense disputes and have had most of their monuments removed; and adjudicating and surveying areas that have not yet been surveyed (about $9 \%$ of Fiji remains to be surveyed). In addition to being beyond what Fiji may be able to afford, the cost of undertaking this task could well be out of proportion to the benefits that the indigenous Fijians would obtain from the LIS.

However given the importance of land for the development of the taukei, and the ever increasing pressure for its use, a very strong argument can be made that all native land boundaries and all pertinent customary land tenure interests within, need to be properly recorded and registered.

Efforts must be made to develop a LIS that is best adapted and most appropriate for the needs and conditions of the lands held under customary tenure in Fiji. Perhaps a way of alleviating the spatial aspect of the problem is to adopt the English concept of "general boundaries" for the spatial definition of lands held under customary tenures. This would allow the necessary attributes to be documented, but without the unnecessary need to also locate them accurately.

Another problem in Fiji is that the indigenous populace still exist largely in a culture that pays great respect to the idea of authority, and respect for authority does not sit easily with the general sense of individual self-sufficiency required by a market driven economy.

\section{Institutional Issues}

There is a need for all institutions to acknowledge and act on the fact that the knowledge of and ready access to existing information that the LIS could provide, is both economical and time saving - not only to individual organisations, but also to the people who use the system.

Availability of customary land tenure information to all institutions involved should help avoid, as well as quickly and efficiently resolve, land tenure problems that may arise. To be available data needs first of all to be shared between the agencies and institutions involved.

It may therefore be important to form a steering committee, comprising representatives of each local organisation, to facilitate the exchange of information, and resolve any policy related problems as they arise.

\section{Social and Cultural Issues}

The most critical concern regarding social and cultural issues is that a clear distinction must be made between what needs to be recorded and what would be desirable to have recorded. To be able to do this, it 
is important to always keep in mind the original objectives of the LIS. Since the LIS is largely oriented towards capitalistic and market driven enterprises, a balance may need to be struck between recording customary land tenure data that will help the indigenous Fijians to develop economically (such as documenting existing land uses that are economically successful), and recording customary land tenure data that could facilitate the retention of the valuable parts of their social customs and traditions, such as the fishing and cultivation restrictions that apply when a high chief dies. At the same time however it must be accepted that in order to achieve economic growth, some social customs and traditions may need to be sacrificed.

Obviously not all aspects of customary land tenures can be easily computerised and incorporated into an LIS. Some social and cultural features may not have a readily definable spatial dimension to them, being based on spiritual or sentimental perceptions and beliefs. These social and cultural features can also be very subjective and not easily viewed objectively. For instance the idea of exposing some culturally sensitive areas, such as the tabu areas where ancestral spirits or local gods are believed to reside, to an increasingly materialistic, profit-oriented public that could be insensitive to the underlying beliefs involved, would be abhorrent to the indigenous peoples. As Chapelle (1978) rightly pointed out, these lands were not cultivated, let alone walked on, with access to them being controlled by the descent groups in the area. Consequently, as long as the LIS continues to be an unwitting agent for capitalistic exploitation, some caution must be exercised with respect to the features to be considered for incorporation into an LIS. Thus it may be that only those features of customary tenures that contain some incentives for development should be included into an LIS.

Another concern with incorporating attributes of customary tenure into an LIS, is that it could be a potential source of conflict and dissension. Conflicting opinions that have existed since the imposition of a standard land tenure system into the country early this century, would undoubtedly resurface, once inquiries for data capture commenced. For instance people today still have varying opinions of their origins, their land rights, their chiefly entitlements, and so on, even to the extent of privately disputing, within their own communities, the written evidence in the Vola ni Kawa Bula (VKB), and the Tukutuku Raraba. (The $V K B$ is the official Register of Fijians, while the Tukutuku Raraba records the historical origins of each tribal group, and how they came to settle into a particular area in Fiji).

On the other hand however, the LIS may provide the opportunity of resolving once and for all, these 'old wounds and grudges'. For instance it could be the vehicle for recording within each region, the peculiarities and so called irregularities of their social classification, for land-administration purposes, into the hierarchical groups of tokatoka, mataqali, yavusa; and the wider colonialist inspired grouping of vanua and matanitu. Ravuvu (1987) notes for example, how the administrative needs of the Colonialist rulers led to smaller mataqali being immersed by the bigger mataqali and officially erased, despite their (the smaller mataqali ) continuing existence in practice. Likewise the tokatoka of large mataqali were incorporated into other smaller mataqali in order to obtain neat, organised social groups that could be easily administered and controlled.

An area where incorporating customary land tenure data into an LIS will also be another source of conflict lies in the basic fact that people will always have different values and conceptions, and therefore may unintentionally or even deliberately misinterpret and misuse the information made available by a LIS.

Finally another possible social cost of incorporating customary land tenure into an LIS could be the reduced dependency of Fijian society on the elders of the society for information on land matters. Traditionally the elders have always held a specific, even indispensable role to play, in matters concerning land. With time, as the LIS acquires information and becomes a reliable and efficient source of information, the important role that they now have in the community could slowly become redundant. Thus along with other factors of modernisation, the future reliance on the LIS could lead to a change in the traditional roles of the elders of society, which may help to perpetuate a decline in the acceptance of traditional communal values. This could lead to an erosion of traditional values, and the consequent social problems that seem to be prevalent in the individualised western world. 


\section{Technical Issues}

The inherent difficulty of quantifying cultural matters and maintaining and keeping them up to date are some of the technical issues that will need to be considered. For instance, as mentioned earlier, some social and cultural features may not be clearly definable spatially, being spiritually or culturally sensitive areas. Perhaps the answer to the mapping of such features lies with using the concept of indistinct 'fuzzy' boundaries for these features.

Jeyanandan and Williamson (1990) pointed out that attempts to build land information capabilities have often been supply-driven, being closely tied to the commercial or scientific interests of technology suppliers. For developing countries with customary tenures such as Fiji, this has grave implications if the software developers or vendors are insensitive to what to them may be the many frustrating inconsistencies of customary tenures. As a result they may ignore the troublesome features, for the sake of expediency and expense, for their commercial and scientific interests. It is important therefore to have staff trained in the technical aspects of LIS -- for example in programming, database development, networking -- to ensure that the LIS is driven by the needs of the country or organisation involved, and not by the technology, which exists to serve the needs of the public.

\section{Legal Issues}

Two main legal concerns involve access to and liability of customary land tenure information. Access includes questions of ownership, sharing, privacy, political control and cost recovery. Liability includes questions of error, misuse of data and information, and compatibility. As Epstein (1991) pointed out, LIS technology provides new, alternative and efficient means to collect, analyse and disseminate data and information. But if the availability of information products is limited because of access problems, then the potential of LIS will not be fully realised.

As mentioned previously, information may be valued and used differently, according to the perceptions, understanding and intentions of the persons involved. Therefore the possibility that the information made available by an LIS may be unintentionally and even deliberately, misinterpreted and misused, raises some legal concerns.

Other important legal issues involve the questions of custodianship, copyright and confidentiality of information.

To date customary land tenure has been a grey area in matters of law. This may be due largely to the uncertainty of customary land tenures, which has been caused by the lack of documentation and flexibility of customary land tenures. The potentially immense documentation that LIS will incur will enable a potentially infinite number of geographically referenced data sources to be combined. The legal consequences of these combinations are as yet unknown; and still to be tested. The inevitable legal significance of this is that the LIS may affect, and even change the land ownership interests in land. One thing is clear however, and that is that the laws relating to lands under customary tenure (ie. Native Lands) may need to be reviewed and revised, to cater for the full introduction of a LIS.

\section{Political Issues}

Bacon (1984) rightly points out that information is, and always will be, a 'political' resource. This is evident even in Fiji, where public ignorance of customary land tenures and its related issues, has sometimes been misused by politicians. The availability of information through the LIS offers a way of alleviating this. Ironically however, this in itself poses a potential threat to the successful implementation of the LIS, given the fact that some government agents or departments acquire influence from their control over information, and therefore will not readily give up their control over such information. 


\section{Implications of LIS for Fiji's customary land tenures}

Williamson (1982) noted that Lloyd, a former Director of Fiji's Department of Lands, and General Manager of the Native Land Trust Board, had suggested that as long as Fiji's two distinct systems of land law, administration and tenure continued two nations would exist in Fiji, and this "would mitigate against the evolution of a national land management system". LIS however provides an opportunity to disprove this assertion. By recognising and recording the different features of both systems, and continuously monitoring the changes that may occur, a LIS could allow the two land tenure systems to continue to exist concurrently. In this way it will enable land management in Fiji to be a national integrated exercise, and will therefore be beneficial to all people and races in Fiji.

Some concerns which inevitably arise with respect to incorporating customary land tenure into a LIS are:

Will this result in an unintentional but gradual and imperceptible process of converting communallyoriented customary land tenures into capitalistic-oriented western land tenure systems?

By its very nature customary land tenures are as stated earlier, unwritten and based on memory and goodwill; features that enable them to be flexible enough to cope with a variety of circumstances. Incorporating customary land tenure data into an LIS would entail systematically recording all the features, which with an inherently flexible system, varies locally and regionally with time, place and circumstance.

In today's world, the written word almost always take precedence over the spoken word - and certainly over the memories of the human mind. Therefore over time, the LIS could eventually become the authoritative source of customary tenures. There is the danger therefore that the data or features as recorded by the LIS could gradually be taken as the precedent or definitive rule. This would thereby eliminate the flexibility and adaptability of customary land tenure itself, since by its very nature customary land tenure is not recorded and therefore not limited to inflexible rules and conditions. It could also lead to the establishment of individual rights within a customary tenure framework. With time, as the influence of the growing land market strengthens, the customary framework could weaken and be enveloped by the individualistic western land tenure framework. To avoid this problem it must be made clear that in the context of this paper, the LIS is not a Land Registration System, in which features once recorded and codified, become legally recognised. Rather, LIS should only be a tool for documenting information that will enable more informed land management decisions.

Since customary land tenures have withstood the test of time and changing governments, servicing the people's needs adequately without being systematically identified and recorded, why should they now be systematically identified and recorded, using a new technology that is not locally available and may be costly to maintain?

An answer to this question is that customary tenure should be recorded for future posterity, and even for those of the present generations who for various reasons, may not have had, and may never have the opportunity of learning from their knowledgeable elders, the various invaluable features of their customary land tenure systems.

Fiji's future generations will only retain their customary land tenures if they are able to understand and appreciate them. Given the impact of modernisation on the inevitable modifications and possible erosion of traditional values and customs, the LIS provides a way of ensuring that future generations will always be able to understand, appreciate and retain their customary land tenures. In addition the LIS provides the invaluable opportunity of recording and monitoring the changes in its customary land tenure systems that will inevitably occur. 


\section{Conclusions}

This paper recognises that LIS has traditionally been initiated and implemented by government agencies in industrialised countries, with the main objective of improving the administration and management of their land resources.

If it is the intention of either developing or developed countries with customary land tenures to increase the commercialisation of the associated traditional agricultural industry, and enter the property market, then those countries will need to be aware of the possibility that the realisation of these aspirations may conflict with their existing traditional systems and values, and potentially create friction within the traditional society.

Unfortunately it may be difficult for the indigenous people to retain their largely non-commercial traditional systems and values, and still commercialise or monetise their economy. Sacrifices will be required and must be made, if they are to have a viable market economy.

Generally, in countries with customary land tenures, land issues are politically very sensitive and therefore discussion of change is frequently politicised. As a result most political parties are not anxious to reform land policy. Any land policy reform, where required, may therefore need to be instigated by the people themselves, and this can only be brought about when the people are made aware of the positive and negative issues concerning their existing land tenure system. It is here therefore that the LIS could have an important role to play, in making people more aware and informed of the issues involved. In particular LIS have the potential of assisting in the preservation of traditional values and customs by recording customary land tenure data for future generations. This may assist in improving the efficiency of resolving disputes and claims concerned with land rights and compensation. It may also assist in protecting important ancestral or sacred sites by ensuring foreigners or land developers are sensitive to traditional values and customs, and finally LIS may support environmental and conservation practices by permitting improved monitoring of land use.

A danger, however, with introducing new technologies into a jurisdiction is that people are often led to believe, unintentionally or otherwise, that the new technology will solve all problems associated with it. It must be made clear to all that a LIS is not a panacea for many perceived land related problems; it is only a resource or tool, to be used to assist in solving problems. It is only the decision makers, be it the government or the people themselves, who can resolve the complex social and political issues concerned with customary land tenure.

The objective of this paper was to highlight the weaknesses of adopting the western LIS concept in traditional societies using customary land tenure and to examine the implications of incorporating customary land tenure data into an LIS. Due to the complexities associated with customary land tenures it has not been possible to make any firm recommendations other than LIS do offer the possibility of improved land management in sympathy with traditional values and customs. On the other hand simply by raising the issues described in this paper, the authors believe a positive contribution has been made to understanding the role of LIS in countries using customary land tenures.

\section{References}

Bacon, C.J. (1984), "Land information in the traditional rural sector of developing countries", Proceedings of the FIG Symposium on Land Information Systems, Edmonton, Canada.

Chapelle, T. (1978), "Customary land tenure in Fiji: old truths and middle-aged myths", Journal of the Polynesian Society 87, 2:72-88.

de Soto, H. (1993), "The Missing Ingredient : What poor countries will need to make their rules work", 
The Economist, 328, 7828:8-10

Epstein, E.F. (1991), "Legal Aspects of GIS". In: Maguire, D.J., M.F. Goodchild and D.W. Rhind (eds), Geographic Information Systems: Principles and Applications, London: Longman, pp. 489-502.

Falloux, F. (1989), "Land Information and Remote Sensing for Renewable Resource Management in SubSahara Africa - A demand driven approach". World Bank Technical Paper No 108, The World Bank, Washington, DC.

Jayanandan, D. and I.P.Williamson (1990), "Land information needs of developing countries".

Proceedings from the National Conference on Cadastral Reform'90, Department of Surveying and Land Information, The University of Melbourne, pp81-93.

Noronha, R. and F. J. Lethem (1983), "Traditional Land Tenures and Land Use Systems in the Design of Agricultural Projects". World Bank Staff Working Paper No 561, Washington, DC: The World Bank.

Ravuvu, A. (1987), The Fijian Ethos, Institute of Pacific Studies, University of South Pacific, Suva.

Williamson, I.P. (1982), "The cadastral survey requirements of developing countries in the Pacific region - with particular reference to Fiji", The Survey Review, vol 26, no 206:355-366.

\section{Glossary of Terms and Acronyms}

ai sevu Offering of first fruits of land to chiefs (Fiji)

ALTA Agricultural Landlord and Tenants Act (Fiji)

lala The right of a chief to call upon his people to perform services for him, e.g. to do his gardening or house building (Fiji)

LIS Land information system

matanitu Government or state (Fiji)

mataqali The exogamous social unit of the Fijians. It is patrilineal and is the recognised land-owning group. It is a subdivision of a yavusa, and is usually a primary division of the village.

PID Parcel Identifier

sevusevu A presentation of yaqona made to welcome a visitor or to make a request for a favour or some services.

tabu That which is sacred or forbidden (Fiji)

taukei Indigenous Fijians

tokatoka An extended family; a branch of a mataqali (Fiji)

Tukutuku Raraba A formal record of the historical origins of each tribal group, as related by the tribal groups to the Native Land Commission sittings (Fiji)

vakavanua Customary (Fiji)

vanua Land, or an association or confederation of yavusa under a chief (Fiji)

VKB Vola ni Kawa Bula - The Register of indigenous Fijians 
yavusa The widest Fijian kinship group. It has a name and an honorific title; it has one senior chief; and it may have one totem of its own. A common ancestor and an ancestral god. Descent within it is patrilineal. Its primary subdivisions are known as mataqali. 


\section{University Library}

\section{- M M I N E R VA A gateway to Melbourne's research publications}

Minerva Access is the Institutional Repository of The University of Melbourne

Author/s:

Rakai, Mele E. T.;Williamson, Ian P.

Title:

Implications of incorporating Customary Land Tenure Data into a Land Information System

Date:

1995

Citation:

Rakai, M. E. T., \& Williamson, I. P. (1995). Implications of incorporating Customary Land Tenure Data into a Land Information System. Trans Tasman Surveyor, 1(1), 29-38.

Publication Status:

Published

Persistent Link:

http://hdl.handle.net/11343/34011 